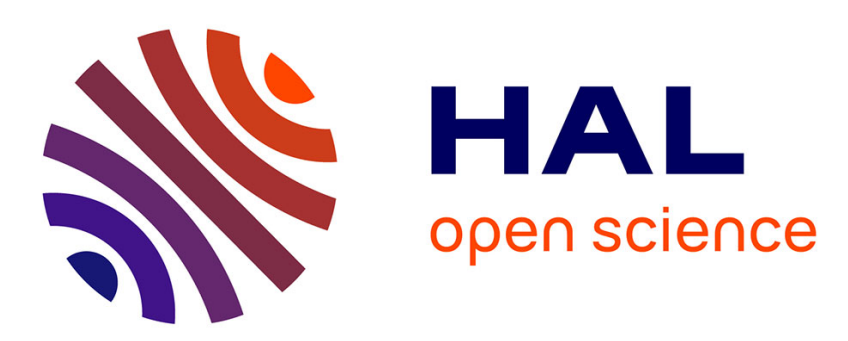

\title{
Characterization of a tachykinin signalling system in the bivalve mollusc Crassostrea gigas
}

\author{
Marie-Pierre Dubos, Sven Zels, Julie Schwartz, Jeremy Pasquier, Liliane
}

Schoofs, Pascal Favrel

\section{To cite this version:}

Marie-Pierre Dubos, Sven Zels, Julie Schwartz, Jeremy Pasquier, Liliane Schoofs, et al.. Characterization of a tachykinin signalling system in the bivalve mollusc Crassostrea gigas. General and Comparative Endocrinology, 2018, 10.1016/j.ygcen.2018.05.003 . hal-01838268

\section{HAL Id: hal-01838268 \\ https://hal.sorbonne-universite.fr/hal-01838268}

Submitted on 13 Jul 2018

HAL is a multi-disciplinary open access archive for the deposit and dissemination of scientific research documents, whether they are published or not. The documents may come from teaching and research institutions in France or abroad, or from public or private research centers.
L'archive ouverte pluridisciplinaire HAL, est destinée au dépôt et à la diffusion de documents scientifiques de niveau recherche, publiés ou non, émanant des établissements d'enseignement et de recherche français ou étrangers, des laboratoires publics ou privés. 


\section{Characterization of a tachykinin signalling system in the bivalve mollusc}

\section{Crassostrea gigas.}

3 Marie-Pierre Dubos ${ }^{1}$, Sven Zels ${ }^{2}$, Julie Schwartz ${ }^{1}$, Jeremy Pasquier ${ }^{1}$, Liliane Schoofs ${ }^{2}$ and 4 Pascal Favrel ${ }^{1 \#}$.

5

6

${ }^{1}$ Normandy University, Université de Caen Normandie, UMR BOREA, MNHN, UPMC, UCBN, CNRS-7208, IRD-207, Esplanade de la Paix, 14032Caen Cedex, France.

${ }^{2}$ Department of Biology, Functional Genomics and Proteomics Group, KU Leuven, 3000 Leuven, Belgium.

\# Corresponding author: pascal.favrel@unicaen.fr, Tel: +33231565361

\section{Abstract}

Although tachykinin-like neuropeptides have been identified in molluscs more than two decades ago, knowledge on their function and signalling has so far remained largely elusive. We developed a cell-based assay to address the functionality of the tachykinin G-protein coupled receptor (Cragi-TKR) in the oyster Crassostrea gigas. The oyster tachykinin neuropeptides that are derived from the tachykinin precursor gene Cragi-TK activate the CragiTKR in nanomolar concentrations. Receptor activation is sensitive to Ala-substitution of critical Cragi-TK amino acid residues. The Cragi-TKR gene is expressed in a variety of tissues, albeit at higher levels in the visceral ganglia (VG) of the nervous system. Fluctuations of Cragi-TKR expression is in line with a role for TK signalling in C. gigas reproduction. The expression level of the Cragi-TK gene in the VG depends on the nutritional status of the oyster, suggesting a role for TK signalling in the complex regulation of feeding in C. gigas.

Keywords: Mollusc, neuropeptide, Tachykinin signalling, feeding 


\section{Introduction}

Tachykinins (TKs) represent a large family of evolutionarily conserved brain/gut peptides in

bilaterian animals. In mammals, the TK peptide family derives from alternate processing of three TAC genes [1] (for review). TAC1 encodes substance P (SP), neurokinin A (NKA) as well as neuropeptide K (NPK) and neuropeptide $\gamma(\mathrm{Np} \gamma)$ [2]. TAC3 (designated as TAC2 in rodents) only encodes neurokinin B (NKB) [3]. A third gene, TAC4 encodes endokinins A, B, $\mathrm{C}$ and D (EKA-D) as well as hemokinin-1 (HK-1) [4]. These genes are conserved from mammals to teleosts [5] and a gene encoding two TK peptides was also characterized in the urochordate Ciona intestinalis [6]. Outside the chordate phylum, TKs have also been characterized in insects, crustaceans, molluscs and annelids [7,8] (for review).

Chordate TK sequences display the conserved C-terminal pentapeptide signature FXGLMamide, whereas protostome TKs share the C-terminal consensus sequence $\mathrm{FX}_{1} \mathrm{GX}_{2} \mathrm{R}$-amide. Interestingly, some vertebrate-type TKs, derived from a distinct gene, have been identified in the salivary glands of cephalopod molluscs $[9,10]$ and insects [11] serving respectively as neurotoxins [12] and as vasodilatory agents that act on vertebrate prey TK receptors (TKR) but not on endogenous receptors [13].

TKs are widely distributed in the nervous systems of all bilaterian animal species. They have been shown to display regulatory roles in an extraordinarily diverse range of physiological processes. In addition to their modulatory role in the central control of respiration and cardiovascular activity, TKs, mainly via SP, also mediate pain, anxiety and motor coordination in the CNS of mammals $[14,15]$. In arthropods, TKs are involved in odour perception and locomotion as shown in Drosophila [16] and in visual processing as suggested in crustaceans [17]. In bilateria, TKs have been shown to participate in the control of the activity of a wide 
species suggest that TK signalling plays a role in the regulation of gut activity and visceral and skeletal muscle contractions [18-21]. Deficient TK functioning contributes to multiple disease processes in humans [1].

In contrast to Ecdysozoa [22], which comprises arthropods and nematodes as major phyla, TK signalling has so far been largely unexplored in Lophotrochozoa, the protostome sister group of the Ecdysozoa. Only two studies, respectively in Octopus [13] and in the lophotrochozoan worm $U$. unitinctus [23], reported on the identification of a TKR in Lophotrochozoa. In bivalve molluscs, TK peptides have been molecularly characterized more than two decades ago in the mussel Anodonta cygnea [24] and more recently in the oyster Crassostrea gigas [25]. The recent development of an extended transcriptomic database of C. gigas [26] offers the opportunity to characterize neuropeptide receptors and thus establish their physiological role(s).

The present study reports on the characterization of a TKR in the oyster $C$. gigas and shows that it is functionally activated by oyster TKs. In addition, we investigated the structure-activity relationship of ligand-receptor pairs by assessing the potency of a series of synthetic TK analogues. In order to further explore TK signalling in C. gigas, we determined the expression patterns of the genes encoding the TK precursor and the TKR at successive reproduction stages as well as in distinct nutritional conditions.

\section{Material and methods}

\section{Peptide synthesis}

All peptides were custom synthesized by GeneCust (Luxemburg). The sequences of C. gigas peptides were obtained from an in-house peptide database yielded by mass spectrometry analyses of tissue extracts and data mining [25].

\section{In silico analyses}


Multiple sequence alignment was performed with TKR from various species (supplementary table 1) using Clustal W [27]. To determine the relationship between Cragi-TKR and TKRs from other species (supplementary table 2), a phylogenetic tree was generated by the maximum likelihood method using the phylogeny pipeline (www.phylogeny.fr) [28] connecting the following programs: MUSCLE for multiple alignment (full processing mode), Gblocks for alignment curation (minimum length of a block after gap cleaning: 10, no gap positions allowed in the final alignment, all segments with contiguous non-conserved positions higher than 8 rejected, minimum number of sequences for a flank position: $85 \%$.), PhyML for phylogeny (the default substitution model was chosen assuming an estimated proportion of invariant sites and 4 gamma-distributed rate categories to account for rate heterogeneity across sites. The gamma shape parameter was estimated directly from the data Model). The reliability of internal branches was evaluated using an approximate likelihood-ratio test (aLRT). TreeDyn was used for tree drawing.

\section{Reverse endocrinology}

Molecular cloning of the Cragi-TKR and transfection of mammalian cells:

In silico screening of the oyster transcriptomic database "GigaTon" [26] resulted in the identification of a full length cDNA encoding Cragi-TKR (CHOYP_LOC100744404.1.1). The CDS of the Cragi-TKR gene was amplified by PCR (Pfu DNA polymerase, Promega) using gene-specific sense primer (5'-CACCATGGAGGGGAACAATTCAACAAAAG-3') harbouring a Kozak consensus sequence and antisense primer (5'TCATAAATATTCAGCACTAGTTCTCCGCCC-3'). Ten nanogram of plasmid DNA (Pal 17.3 vector, Evrogen) from a $C$. gigas "all developmental stages and adult central nervous system" directional and normalized cDNA library [29] was used as template. The resulting PCR product was directionally cloned into the eukaryotic expression vector pcDNA3.1 (Invitrogen) and the correct insertion confirmed by sequencing. Human embryonic kidney (HEK293T) cells 
were transiently transfected with the Cragi-TKR/pcDNA3.1 construct using Fugene HD

101 (Promega) according to the manufacturer's instructions. As a first step, co-transfection was

102 done with an expression construct for the human $\mathrm{G} \alpha_{16}$ subunit, a promiscuous $\mathrm{G}$ protein that

103 can direct intracellular signalling of GPCRs to the release of calcium via the phospholipase $\mathrm{C}_{\beta}$

104 pathway, regardless of the endogenous G protein coupling of the receptor (Mertens et al, 2004).

105 To assess receptor activity independent of $\mathrm{G} \alpha_{16}$, calcium responses were measured in cells

106 expressing only Cragi-TKR. Cells for negative control experiments were transfected with empty 107 pcDNA3.1 and $\mathrm{G} \alpha_{16} / \mathrm{pcDNA} 3.1$ constructs.

\section{Calcium fluorescence assay:}

109 Activation of Cragi-TKR by oyster TK synthetic peptides was monitored using a fluorescence-

110 based calcium mobilization assay. Briefly, transfected HEK293T cells were loaded with Fluo-

1114 Direct plus probenecid (qsp 2.5mM final in the cell) (Invitrogen / Molecular Probes) for 1

112 hour $\left(45 \mathrm{~min}\right.$ at $37^{\circ} \mathrm{C}$ and $15 \mathrm{~min}$ at room temperature). Excitation of the fluorophore was done

113 at $488 \mathrm{~nm}$. The calcium response was measured for 2 min at $525 \mathrm{~nm}$ using the FLEXstation 3

114 (Molecular Devices) at $37^{\circ} \mathrm{C}$. Data were analysed using SoftMax Pro (Molecular Devices).

115 Candidate peptide ligands were first tested at a final concentration of $10^{-5} \mathrm{M}$. Concentration-

116 response measurements of activating ligands were conducted in triplicate and for at least three

117 independent experiments. Half maximal effective concentrations $\left(\mathrm{EC}_{50}\right.$ values) were calculated

118 from concentration-response curves that were constructed using nonlinear regression analysis

119 with a sigmoidal dose-response equation using Prism 5.0 (GraphPad software, USA).

121 cAMP luminescence assay.

122 Cragi-TKR transfected HEK 293T cells were incubated with Glosensor cAMP reagent (qsp 4\%

123 final in the medium) (Promega) for 2 hours at room temperature prior to the injection of the 
124 candidate ligands. .cAMP luminescence response was measured for $30 \mathrm{~min}$ after injection using

125 a FLEX station 3 (Molecular Devices) at room temperature. Data were analysed using SoftMax

126 Pro (Molecular Devices). Candidate peptide ligands were first tested at a final concentration of $127 \quad 10^{-5} \mathrm{M}$.

128

129

\section{Animals and tissue sampling}

Two-year old adult oysters C. gigas, purchased from a local farm (Normandie, France), were used for peptide characterization and transcription analyses. Stages of reproduction (Stage 0: resting undifferentiated stage, Stage 1: gonial multiplication stage, Stage 2: maturation stage, Stage 3: sexual maturity) were determined by histological analysis of gonad sections as described previously [31]. To study the influence of trophic conditions, one-year-old adult oysters were reared in water tanks either in absence of food or in presence of Isochysis galbana (clone T-Iso) maintained at a concentration of 6 million of cells $/ \mathrm{mL}$ during 4 weeks. Adult tissues (mantle, gill, labial palps, digestive gland, gonad, hemolymph, adductor muscle) were sampled, the visceral ganglia (VG) were carefully dissected out, thus limiting any contamination from the adjacent adductor muscles. All the samples were either placed in TriReagent (Sigma) or stored at $-80^{\circ} \mathrm{C}$ until use. For expression studies, adult tissues or VG and gonads during gametogenesis from 6 animals were mixed to generate 5 pools of each tissue. Individual VG from 19 and 17 animals were used to study gene expression in fed and starved animals respectively.

\section{Reverse transcription quantitative PCR (RT-qPCR)}

RT-qPCR analysis was performed using the iCycler iQ@ apparatus (Bio-Rad). Total RNA was isolated from adult tissues using Tri-Reagent (Sigma-Aldrich) according to the manufacturer's instructions. Recovered RNA was further purified on Nucleospin RNAII columns (MachereyNagel). After treatment during $20 \mathrm{~min}$ at $37^{\circ} \mathrm{C}$ with $1 \mathrm{U}$ of DNase I (Sigma) to prevent genomic 
148 DNA contamination, $1 \mu \mathrm{g}$ of total RNA was reverse transcribed using $1 \mu \mathrm{g}$ of random

149 hexanucleotidic primers (Promega), $0.5 \mathrm{mM}$ dNTPs and $200 \mathrm{U}$ MMuLV Reverse Transcriptase

150 (Promega) at $37^{\circ} \mathrm{C}$ for $1 \mathrm{~h}$ in the appropriate buffer. The reaction was stopped by incubation at

$15170^{\circ} \mathrm{C}$ for $10 \mathrm{~min}$. The GoTaq ${ }^{\circledR}$ qPCR Master Mix (Promega) was used for real time monitoring

152 of amplification ( $5 \mathrm{ng}$ of cDNA template, 40 cycles: $95^{\circ} \mathrm{C} / 15 \mathrm{~s}, 60^{\circ} \mathrm{C} / 15 \mathrm{~s}$ ) with the following

153 primers: Qs-Cragi-TKR (5'-ATGGCCCACAAGCGGATG-3') and Qa-Cragi-TKR (5'-

154 GGTGGACACAAACGCCGT-3') as sense (Qs) and antisense (Qa) primers for Cragi-TKR

155 cDNA and Qs-Cragi-TK (5'-GCATACCAGAATCATCAA-3') and Qa-Cragi-TK (5'-

156 GTTTATTGTTCCGAACTAAT -3') for Cragi-TK precursor cDNA. Accurate amplification of

157 the target amplicon was checked by performing a melting curve analysis. Using Qs- $C g$-EF (5'-

158 ACCACCCTGGTGAGATCAAG-3') and Qa-Cg-EF (5'-ACGACGATCGCATTTCTCTT-3')

159 primers, a parallel amplification of oyster Elongation Factor $1 \alpha(\mathrm{EF} 1 \alpha)$ transcript

160 (BAD15289) was carried out to normalize the expression data of Cragi-TKR and Cragi-TK

161 transcripts. EF1 $\alpha$ was found as a reliable normalization gene as no significant difference

$162(\mathrm{p}<0.05)$ of $\mathrm{Ct}$ values was observed between the different samples compared. Coefficient of

163 variation of EF1 $\alpha$ was less than 5\%. Thus, the relative level of each gene expression was

164 calculated for one copy of the EF1 $\alpha$ reference gene by using the following formula: $N=2^{\text {(Ct }}$

$165 \mathrm{EF} 1 \alpha-\mathrm{Ct} C g$-CDNA) . The PCR amplification efficiency $\left(\mathrm{E} ; \mathrm{E}=10^{(-1 / \mathrm{slope})}\right)$ for each primer pair was

166 determined by linear regression analysis of a dilution series to ensure that E ranged from 1.98

167 to 2.02 . The specificity of the primer pairs was confirmed by melting curve analysis at the end

168 of each RT-qPCR run.

\section{Statistical analysis}

170 Gene expression levels between different tissues and between samples at different reproduction

171 stages were compared using one-way ANOVA followed by a Tukey post hoc test. Expression

172 levels between fed and starved animals were compared using an unpaired Student's t test. 
Significance was set at $\mathrm{p}<0.05$.

174

175

176

177

\section{Results:}

Molecular characterization of an oyster tachykinin receptor (Cragi-TKR).

The unique sequence displaying homology with vertebrate and protostome TKRs was retrieved from GigaTON, an oyster comprehensive transcriptomic database [26]. Alignment of $C$. gigas receptor (Cragi-TKR) with other receptors of the family displays an overall identity of $42 \%$ with Octopus TKRPR and 32\% with Drosophila DTKR and human TKR1 (Fig. 1). A phylogenetic analysis clearly showed that Cragi-TKR clustered with predicted or functionally characterized mollusc TKRs and as a separate branch from the insect TKRs. Annotated orphan nematode TKRs appeared more distant and emerged as a separate branch. All vertebrate TKrelated receptors including the three distinct classes of NK receptors (NK1R, NK2R and NK3R) formed a distinct clade (Fig.2). Alignment of the Cragi-TKR cDNA with C. gigas genomic sequence (http://www.oysterdb.com) identified a gene (CGI_10007698) organized into 5 exons with 4 introns shared at conserved positions and with the same intron phasing with the receptors from vertebrate and protostome species $[23,32]$ suggesting an evolution from a gene already present in the bilaterian common ancestor.

\section{Oyster TKs specifically activate Cragi-TKR.}

A calcium mobilization assay was used to identify the cognate ligands of Cragi-TKR [33]. Transiently transfected HEK293T cells expressing the oyster receptor and the promiscuous G protein $\mathrm{G} \alpha_{16}$ were challenged with the three oyster synthetic TKs (Cragi-TK1: FGFAPMRamide, Cragi-TK2: ARFFGLR-amide and Cragi-TK3: FRFTALR-amide). These TKs are derived from the Cragi-TK neuropeptide precursor by posttranslational processing (Fig.3A) and have previously been characterized as part of $C$. gigas ' repertoire of neuropeptides [25]. Since Cragi-TKR was equally activated with high doses $\left(10^{-5} \mathrm{M}\right)$ of all three Cragi-TK peptides in 
presence or absence of the promiscuous G $\alpha_{16}$ protein (supplementary Figure 1), a dose-

199 dependent activation of Cragi-TKR was recorded by omitting the G $\alpha_{16}$ protein (Fig.3B). Half maximal effective concentrations $\left(\mathrm{EC}_{50}\right)$ were of $4.1 \mathrm{nM}$ for Cragi-TK2, $4.6 \mathrm{nM}$ for Cragi-TK1 and $11.5 \mathrm{nM}$ for Cragi-TK3. No signal was observed with cells transfected with an empty vector 202 or with high concentrations $\left(10^{-5} \mathrm{M}\right)$ of the oyster GALRF-amide unrelated peptide used as 203 negative control [33].

204 To determine the residues that are critical for receptor activation, a series of alanine-substituted analogues of Cragi-TK2 were assessed (Fig.4). The activity of the different analogues can be ranked into three main groups, a first one including the peptides displaying a high $\mathrm{EC}_{50}$ corresponding to the $\left[\mathrm{Arg}^{7}\right]$ and $\left[\mathrm{Phe}^{3}\right]$ alanine-substituted peptides, a second group comprising $208\left[\mathrm{Arg}^{2}\right]$ and $\left[\mathrm{Phe}^{4}\right]$ alanine-substituted peptides for which the modification only moderately 209 affected the potency and a third group including the $\left[\mathrm{Gly}^{5}\right]$ and $\left[\mathrm{Leu}^{6}\right]$ alanine-substituted peptides displaying a higher potency than the naturally occurring peptides (Table 1). All these 211 agonists displayed the same efficacy. None of the three naturally occurring peptides or the 212 alanine substituted peptides activate the cAMP signalling pathway even at concentrations as 213 high as $10^{-5} \mathrm{M}$.

\section{Gene expression of Cragi-TKR and Cragi-TK.}

215 The expression of Cragi-TKR and of Cragi-TK genes was analysed by RT-qPCR. Cragi-TKR 216 was found to be mainly expressed in the visceral ganglia and to a lower level in a majority of 217 adult tissues including, the gills, the adductor muscle, the heart, the mantle, the gonads, the 218 labial palps and the digestive gland (Fig.5A). To determine a possible involvement of TK 219 signalling in the regulation of oyster reproduction, Cragi-TKR gene expression was assayed in 220 the visceral ganglia and in the gonads along the reproductive cycle (Fig.5B). Except a slight 221 peak of expression in females during vitellogenesis (stage2), Cragi-TKR gene expression did 222 not fluctuate significantly in the visceral ganglia. In the gonads, Cragi-TKR gene expression 
was maximal in undifferentiated gonads (Stage 0) and gradually declined along the reproductive

224 cycle in both males and females. Besides, Cragi-TK gene was chiefly expressed in the visceral 225 ganglia and at basal levels in the mantle, the adductor muscle and the labial palps (Fig.5C). No 226 significant differential expression of Cragi-TK gene was noticed along the reproductive cycle 227 in the visceral ganglia (Fig.5D). Interestingly, Cragi-TK gene, but not Cragi-TKR gene, was 228 significantly more expressed in four weeks starved animals than in fed animals (Fig.5E and F).

\section{Discussion.}

230 TK signalling systems have been extensively studied in a vast number of animal species. Mature

231 TKs were first biochemically isolated and identified and as a result of the development of 232 molecular biology approaches and genomics, the characterization of their precursor as well as 233 their cognate receptors has become accessible. By mining C. gigas comprehensive 234 transcriptomic [26] and genomic [34] databases, a unique receptor (Cragi-TKR) displaying consistent homology and phylogenetic proximity with vertebrate and insect TKRs has been identified. In contrast, vertebrate [1] and Drosophila [35,36] genomes encode respectively three and two TKR types. Diverse TKs (SP, NKA, NKB) derived from distinct peptide precursor genes, activate vertebrate TKR with distinct potencies [1]. In Drosophila, all TK peptides

239 derived from the TK-related neuropeptide precursor gene activate the DTKR with different potencies [37]. The other Drosophila receptor (NKD), is activated in vitro by only one of these six TKs (DTK-6) albeit at high concentrations [38]. Finally, NKD turned out to represent the bona fide receptor for Drosophila natalisins, a family of insect neuropeptides that are derived

243 from a distinct neuropeptide precursor gene. Natalisins promote insect reproduction and also 244 display the C-terminal FXXXRamide motif common to all protostomian TKs [39].

245 In all lophotrochozoan species investigated so far, only one specific TKR has been identified 246 [13,23]. The occurrence of a natalisin type of receptor is unlikely in C. gigas since no 247 homologous neuropeptide has been found among the exhaustive neuropeptide repertoires of 
oyster [25] and other Lophotrochozoa [40,41]. Moreover, our phylogenetic study suggests that

249 arthropod-specific natalisin receptors may have arisen from a recent duplication during the 250 evolution of arthropods.

251 Cragi-TKR behaves as a genuine TKR. Similar to its vertebrate and protostome counterparts, it 252 is specifically and slightly selectively activated by all three oyster TKs encoded by the oyster 253 TK precursor at concentration ranges similar to those required for the activation of TKRs in 254 other species [23,37,42]. Similar to the Octopus TKR [13], Cragi-TKR triggers in vitro only 255 the phospholipase $\mathrm{C} \beta$-mediated calcium transduction pathway, a feature distinct to some insect and vertebrate receptors which additionally transduce their signal via an increase in cAMP 257 levels [36,43-45]. Although distinct in sequence, Cragi-TKs exhibit only minor potency differences suggesting that they may be functionally redundant. To determine the essential amino acids of Cragi-TKs, a structure activity relationship analysis was performed using a series of synthetic analogues of Cragi-TK2 (ARFFGLR-amide) in which each amino acid was sequentially replaced by the neutral alanine residue. Considering the $\mathrm{C}$-terminal consensus

$262 \mathrm{FX}_{1} \mathrm{GX}_{2}$ Ramide sequence of protostome TKs, only the replacement of the terminal Arginine or the first Phenylalanine showed drastic negative effects consistent with the high conservation of these two residues possibly due to a strong selective pressure during the evolution of protostome TKs. This also reflects the low activity reported for chordate-type TKs (harbouring a C-terminal methionine instead of an arginine) on protostome receptors $[13,23,46]$. Change of the $\mathrm{N}$ 267 terminal extension of Cragi-TK2 did not alter significantly the neuropeptide activity. As expected, change of the flexible residue $\left(\mathrm{X}_{1}\right)$ of the consensus sequence resulted in only limited effects on the activation of Cragi-TKR. Surprisingly, Cragi-TKR showed higher sensitivity to peptide analogues with an alanine replacing either the conserved Glycine or the penultimate $271\left(\mathrm{X}_{2}\right)$ residue. The glycine residue does not appear to be crucial since the three naturally 272 occurring oyster TKs display a variability of residues at this position. Interestingly both Cragi- 
273 TK3 and the bivalve mollusc Anodonta cygnea TK hold an alanine at this position [24]. Such 274 naturally occurring alanine-containing TKs also exist in insects [47,48], and were proven more 275 potent than their glycine-containing counterparts but behave as partial agonists due to reduced maximal calcium mobilisation efficacy [49]. Partial agonistic activity and transduction pathway

277 plasticity in insect and mammalian neurokinin signalling were suggested to reflect the existence 278 of multiple receptor conformation states $[49,50]$ that may disclose a potential fine-tuning of 279 physiological processes. Unexpectedly such a situation does not appear to exist in oyster since 280 all peptides show equivalent efficacy.

281 The expression of Cragi-TKR in a wide variety of oyster organs and tissues clearly conforms 282 with the pleiotropic regulatory role of TKs in other animal groups. As for other molluscs, the 283 central nervous system represents the unique source of TKs, a situation different from insects 284 where gut endocrine cells also contribute to the production of this family of peptides [51] 285 suggesting a possible link with the digestive processes and feeding. The increased expression level of the Cragi-TK gene in the CNS of starved oysters suggests a role in feeding behaviour. However, it is not well-defined whether this activity is exerted centrally, likely initiated through nutrient sensing, via the control of neuronal feeding circuits or peripherally at the level of the 289 gills and labial palps -the main food collector organs- or the digestive tract. In mice, Tac1 290 (SP/neurokinin A) controls circadian feeding behaviour and metabolism [52]. Likewise in 291 insects, TKs injected in starved Bombyx mori larvae induce a stimulatory effect in feeding 292 behaviour by reducing the period of latency to the first bite [53]. The content of mature TKs 293 was also affected in the brain of honey bees in association with nectar and pollen foraging 294 suggesting a role in this social behaviour [54]. Given the involvement of TKs in olfactory and 295 locomotion behaviour in Drosophila [16], it was proposed that TK signalling could play a role 296 in the perception, the localisation of a food source and its collection [54]. Such hypothesis fits 297 the presence of Cragi-TKR in the gills and the labial palps, the oyster organs implicated in the 
collection and sieving of food particles. In vertebrates and insects, the digestive tract also

299 represents an important target for TKs. In the mammalian intestine, TKs mainly released from 300 neurons control the activity of neuronal networks, influence fluid secretion and act on smooth 301 muscles [55]. Similarly, TKs stimulate in vitro contractions of the gut in insects [20] and also 302 regulate enterocyte lipid production and systemic lipid homeostasis in Drosophila [56]. 303 However, this later activity is mainly controlled by TKs released from enteroendocrine cells, 304 the peptide content of which increases in starved animals. The weak expression of Cragi-TKR 305 in the oyster digestive gland is consistent with a role of TKs in lipid metabolism. However, the lack of TK gene expression and the absence of endogenous TKs in this organ implies a regulation by TKs released as a circulating neurohormone. It is intriguing that, with the singular exception of the AKH signalling system [57], most oyster neuroendocrine systems investigated

309 so far appear sensitive to the nutritional status [33,58]. This reflects the complexity of the 310 feeding control in animals and emphasizes the requirement of a fine regulation to support 311 constant energy needs in a context of sporadic food availability. That TK signalling also 312 regulates the activity of oyster gonad cells was suggested by the fluctuating Cragi-TKR 313 expression during the reproductive cycle. This is reminiscent of the role of TKs in the regulation 314 of reproduction-associated processes in both vertebrate and protostome species. Indeed, TKs were shown to participate in the neuroendocrine control of reproduction in mammals $[59,60]$ and fish [61], in the regulation of oocyte growth in the ascidian C. intestinalis [62] and in the

317 oviducal myotropic activity in the locust [20].

\section{Conclusion}

319 We have characterized in the oyster $C$. gigas, a TK signalling system that appears to share common features with that of other animal species: (1) an involvement in the regulation in a 321 variety of physiological processes implied by a distribution of the TK receptors in diverse 322 organs (2) a potential feeding modulating activity of TK peptides suggested by a marked 
increase in expression of their encoding gene in the CNS of starved oysters, (3) a likely role in

regulating reproduction processes in line with the variability of expression of TK signalling components along the reproductive cycle. In contrast to vertebrates and insects, oyster and other protostome species [8] express their TK gene in the central nervous system but not in the gut.

\section{Acknowledgments.}

This work was funded by the ANR project "NEMO" (ANR 14CE02 0020). J. Schwartz PhD fellowship was co-financed by the NEMO project and a by the European Union in the frame of the operational program FEDER/FSE 2014-2020. S. Zels is a postdoctoral research fellow of the Research Foundation - Flanders (FWO). L. Schoofs and S. Zels wish to acknowledge the European Research Council (ERC grant 340318) and the Research Foundation - Flanders (FWO grant G069713N and G0C0618N) for financial support.

\section{Figure legends:}

Figure 1: Sequence alignment of the Cragi-TKR and TKR family members.

The amino acid sequence of Crassostrea gigas (Cragi-TKR: MF320350) was aligned with those of Octopus vulgaris (Ov-TRR: Q58A49), Drosophila melanogaster (Dm-DTKR: P30975), Homo sapiens (Hs-NK1R: P25103), Caenorhabditis elegans (Ce-TKRF: O44148) and Ciona intestinalis (Ci-TKR: Q60GS8) using CLUSTALW.

Bars indicate the seven putative TM domains. Identical amino acid residues are highlighted in dark grey and similar residues in light grey. Putative N-linked glycosylation sites (NXS/T) or S, T and Y potential phosphorylated residues are underlined with a dotted line. Amino acid residues in boxes are believed to play a pivotal role in GPCR activation. Arrow heads indicate the position of introns. * indicates functionally characterized receptors. 
349 other TKR family members. The tree was generated by a maximum likelihood method using

350 the phylogeny pipeline (www.phylogeny.fr) [28]. Crassostrea gigas TKR (MF320350)

351 Ancyclostoma ceylanicum TKR (A0A016WHR5), Apis mellifera TRP-R (A0A141CIU0), 352 Aplysia californica TKR (XP_012936179.1), Caenorhabditis elegans TKR (O44148), Ciona 353 intestinalis TKR (Q60GS8), Danio rerio TACR1a (E9QCW0); TACR1b (I6UDB5); TACR2 354 (F1QPL8); TACR3-like (F1R3V0) and TACR3a (H6A6A7), Drosophila melanogaster DTKR 355 (P30975)and NKDR (P30974), Gallus gallus TACR3 (F1NJ82); SPR (Q9W6I3) and TACR2 (E1BRR8), Homo sapiens NK1R (P25103), NK2R (P21452) and NK3R (P29371), Limulus polyphemus TKR (XP_013772923.1), Lottia gigantea (V4BE54), Mus musculus TACR1 (P30548); TACR2 (Q3KP20) and TACR3 (EDL12172.1), Nilaparata lugens GPCR (U3U967), Octopus vulgaris TKR (Q58A49), Octopus bimaculoides TKR (XP_014785645.1) Parasteatoda tepidariorum TKLPR (XP_015910841.1), Stomoxys calcitrans TKLPR (A0A1I8PID0), Toxocara canis TAKR (A0A0B2V4Q7), Varoa destructor TRP-R (A0A141CIT9) were the sequences used to construct the tree. The Cg-sNPFR-like receptor (MF320349) was chosen as outgroup. * indicates functionally characterized receptors. Branch node labels correspond to likelihood ratio test values.

Figure 3: Dose-dependent activity of Cragi-TK peptides on Cragi-TKR expressed in

HEK293T cells. A: schematic representation of Cragi-TK precursor (SP: Signal peptide). B:

369 Concentration-response data evoked by Cragi-TK peptides are shown as relative (\%) to the 370 highest value (100\% activation) for a given peptide. Data are the means of three independent 371 experiments done in triplicate. The C. gigas GALRF-amide peptide was used as negative 372 control. Vertical bars represent the standard error of the mean (SEM). 
Figure 4: Comparison of dose-response relationships of a series of Cragi-TK2 single

amino acid replacement analogues. Fluorescent signal induced by Cragi-TKR expressed in HEK293T cells and challenged by a series of alanine-substituted analogues of Cragi-TK2. Grey shading represents the position of the Cragi-TK2 amino acids replaced by an alanine residue. Data are shown as relative (\%) to the highest value (100\% activation) for a given peptide, and were performed at least in triplicate. Vertical bars represent the SEM.

Figure 5: Expression of Cragi-TKR and Cragi-TK genes. (A) Distribution of mRNAs encoding Cragi-TKR in adult tissues, (B) level of expression of Cragi-TKR mRNA in visceral ganglia (VG) and gonads (GO) during gametogenesis, (C) Distribution of mRNAs encoding Cragi-TK precursor in adult tissues, (D) level of expression of Cragi-TK mRNA in visceral ganglia (VG) along an annual reproductive cycle, (E and F) expression levels of Cragi-TKR and Cragi-TK mRNA respectively in VG of four weeks Isochysis galbana fed or starved oysters, Each value is the mean + SEM of 5 pools of 6 animals (in adult tissues); 5 pools of 6 animals (VG during gametogenesis) and 19 or 17 independent animals (VG after conditioning with or without food). Expression levels were calculated as the number of copies of Cragi-TKR / CragiTK transcripts per $10^{3}$ copies of elongation factor $1 \alpha(\mathrm{EF} 1 \alpha)$ mRNA. Results were statistically tested with a one-way ANOVA (A, B, D and E) or student's t test (C and F), p<0,05. Significantly different means are indicated by different letters (A, B and D) or $* * *(p<0.001)$ (B). No significant statistical difference was observed for (C and E). M: Mantle; G: Gills; LP: Labial Palps; DG: Digestive Gland; Go Gonad; H: heart; AM: Adductor Muscle; VG: Visceral Ganglia; F: Female; M: Male; 0: stage 0 (sexual resting stage); 1: stage 1 (gonial multiplication stage); 2: stage 2 (tubule development and maturation stage); 3: stage 3 (sexual maturity stage) 

receptor activation. Grey shading represents the position of the Cragi-TK2 amino acids replaced by an alanine residue.

401

\section{References.}

403 [1] M.S. Steinhoff, B. von Mentzer, P. Geppetti, C. Pothoulakis, N.W. Bunnett, Tachykinins 404 405

[2] S. Carter, S. Louis, M. Io, Structure, expression and some regulatory mechanisms of the 407 rat preprotachykinin gene encoding substance $\mathrm{P}$, neurokinin $\mathrm{A}$, neuropeptide $\mathrm{K}$, and neuropeptide gamma., J. Neurosci. 10 (1990) 2203-2214.

[4] N.M. Page, N.J. Bell, S.M. Gardiner, I.T. Manyonda, K.J. Brayley, P.G. Strange, P.J. Lowry, Characterization of the endokinins: Human tachykinins with cardiovascular activity, Proc Natl Acad Sci U S A. 100 (2003) 6245-6250.

W. Zhou, S. Li, Y. Liu, X. Qi, H. Chen, C.H.K. Cheng, X. Liu, Y. Zhang, H. Lin, Molecular and Cellular Endocrinology The evolution of tachykinin / tachykinin receptor ( TAC / TACR ) in vertebrates and molecular identification of the TAC3 / TACR3 system in zebrafish ( Danio rerio ), Mol. Cell. Endocrinol. 361 (2012) 202-212. doi:10.1016/j.mce.2012.04.007. H. Metoki, Y. Satou, N. Satoh, Tachykinin and tachykinin receptor of an ascidian, Ciona intestinalis, J. Biol. Chem. 279 (2004) 53798-53805. doi:10.1074/jbc.M408161200.

[7] C. Severini, G. Improta, G. Falconieri-erspamer, S. Salvadori, The tachykinin peptide 
family, Pharmacol. Rev. 54 (2002) 285-322.

424

[8] H. Satake, T. Kawada, K. Nomoto, H. Minakata, H. Satake, T. Kawada, K. Nomoto, Insight into tachykinin-related peptides, their receptors, and invertebrate tachykinins : A review, Zool. Sci. 20 (2003) 533-549.

[9] A. Anastasi, V. Erspamer, The Isolation and amino acid sequence of eledoisin, the active endecapeptide of the posterior salivary glands of eledone, Arch Biochem Biophys. 101 (1963) 56-65.

[10] A. Kanda, E. Iwakoshi-Ukena, K. Takuwa-Kuroda, H. Minakata, Isolation and characterization of novel tachykinins from the posterior salivary gland of the common octopus Octopus vulgaris, Peptides. 24 (2003) 35-43.

[11] D.E. Champagne, J.M.C. Ribeiro, Sialokinin I and II : Vasodilatory tachykinins from the yellow fever mosquito Aedes aegypti, Proc Natl Acad Sci U S A. 91 (1994) 138-142.

[12] T. Ruder, S.A. Ali, K. Ormerod, A. Brust, M.L. Roymanchadi, S. Ventura, E.A.B. Undheim, T.N.W. Jackson, A.J. Mercier, G.F. King, P.F. Alewood, B.G. Fry, Functional characterization on invertebrate and vertebrate tissues of tachykinin peptides from Octopus venoms, Peptides. 47 (2013) 71-76. doi:10.1016/j.peptides.2013.07.002.

[13] A. Kanda, K. Takuwa-Kuroda, M. Aoyama, H. Satake, A novel tachykinin-related peptide receptor of Octopus vulgaris - Evolutionary aspects of invertebrate tachykinin and tachykinin-related peptide, FEBS J. 274 (2007) 2229-2239. doi:10.1111/j.17424658.2007.05760.x.

[14] J. Vanden Broeck, H. Torfs, J. Poels, W. Van Poyer, E. Swinnen, K. Ferket, A. De Loof, Tachykinin-like peptides and their receptors, Ann. N. Y. Acad. Sci. 897 (1999) 374-387.

[15] A.M. Khawaja, D.F. Rogers, Tachykinins: Receptor to effector, Int. J. Biochem. Cell Biol. 28 (1996) 721-738. doi:10.1016/1357-2725(96)00017-9.

[16] Å.M.. Winther, A. Acebes, A. Ferrús, Tachykinin-related peptides modulate odor 
perception and locomotor activity in Drosophila, Mol. Cell. Neurosci. 31 (2006) 399406. doi:10.1016/j.mcn.2005.10.010.

[17] R.M. Glantz, C.S. Miller, D.R. Nässel, Tachykinin-related peptide and GABA-mediated presynaptic inhibition of crayfish photoreceptors, J. Neurosci. 20 (2000) 1780-1790. http://www.ncbi.nlm.nih.gov.ezp-prod1.hul.harvard.edu/pubmed/10684879.

[18] L. Palamiuc, T. Noble, E. Witham, H. Ratanpal, M. Vaughan, S. Srinivasan, A tachykinin-like neuroendocrine signalling axis couples central serotonin action and nutrient sensing with peripheral lipid metabolism, Nat. Commun. 8 (2017) 14237. doi:10.1038/ncomms14237.

[19] L. Schoofs, G.M. Holman, T.K. Hayes, R.J. Nachman, A. De Loof, Locustatachykinin I and II , two novel insect neuropeptides with homology to peptides of the vertebrate tachykinin family, FEBS Lett. 261 (1990) 397-401.

[20] L. Schoofs, G.M. Holman, T.K. Hayes, J. Kochansky, R. Nachman, A. De Loof, Locustatachykinin III and IV : two additional insect neuropeptides with homology to peptides of the vertebrate tachykinin family, Regul. Pept. 31 (1990) 199-212.

[21] T. Ikeda, H. Minakata, K. Nomoto, I. Kubota, Y. Muneoka, Two novel tachykinin464 related neuropeptides in the echiuroid worm, Urechis unicinctus., Biochem Biophys Res Commun. 192 (1993) 1-6.

[22] T. Van Loy, H.P. Vandersmissen, J. Poels, M.B. Van Hiel, H. Verlinden, J. Vanden Broeck, Tachykinin-related peptides and their receptors in invertebrates: A current view, Peptides. 31 (2010) 520-524. doi:10.1016/j.peptides.2009.09.023.

[23] T. Kawada, Y. Furukawa, Y. Shimizu, H. Minakata, K. Nomoto, H. Satake, A novel tachykinin-related peptide receptor: Sequence, genomic organization, and functional analysis, Eur. J. Biochem. 269 (2002) 4238-4246. doi:10.1046/j.14321033.2002.03106.x. 
[24] Y. Fujisawa, Y. Muneoka, T. Takahashi, T. Takao, Y. Shimonishi, I. Kubota, T. Ikeda, H. Minakata, K. Nomoto, T. Kiss, L. Hiripi, An invertebrate-type tachykinin isolated from the freshwater bivalve mollusk, Anodonta cygnea., in: Y Okada (Ed.), Pept. Chem., Protein Research Foundation, Osaka, 1993: pp. 161-164.

[25] M.J. Stewart, P. Favrel, B.A. Rotgans, T. Wang, M. Zhao, M. Sohail, W.A. O'Connor, A. Elizur, J. Henry, S.F. Cummins, Neuropeptides encoded by the genomes of the Akoya pearl oyster Pinctata fucata and Pacific oyster Crassostrea gigas: a bioinformatic and peptidomic survey., BMC Genomics. 15 (2014) 840. doi:10.1186/1471-2164-15-840.

[26] G. Riviere, C. Klopp, N. Ibouniyamine, A. Huvet, P. Boudry, P. Favrel, GigaTON: An extensive publicly searchable database providing a new reference transcriptome in the pacific oyster Crassostrea gigas, BMC Bioinformatics. $16 \quad$ (2015) 401. doi:10.1186/s12859-015-0833-4.

[27] J. Thompson, D. Higgins, T. Gibson, CLUSTAL W: improving the sensitivity of progressive multiple sequence alignment through sequence weighting, position-specific gap penalties and weight matrix choice., Nucleic Acids Res. 22 (1994) 4673-80.

[28] A. Dereeper, V. Guignon, G. Blanc, S. Audic, S. Buffet, F. Chevenet, J.-F. Dufayard, S. Guindon, V. Lefort, M. Lescot, J.-M. Claverie, O. Gascuel, Phylogeny.fr: robust phylogenetic analysis for the non-specialist, Nucleic Acids Res. 36 (2008) W465-9.

[29] E. Fleury, A. Huvet, C. Lelong, J. De Lorgeril, V. Boulo, Y. Gueguen, E. Bachère, A. Tanguy, D. Moraga, C. Fabioux, P. Lindeque, J. Shaw, R. Reinhardt, P. Prunet, G. Davey, S. Lapègue, C. Sauvage, C. Corporeau, J. Moal, F. Gavory, P. Wincker, F. Moreews, C. Klopp, M. Mathieu, P. Boudry, P. Favrel, Generation and analysis of a 29 , 745 unique Expressed Sequence Tags from the Pacific oyster ( Crassostrea gigas ) assembled into a publicly accessible database : the GigasDatabase, BMC Genomics. 15 (2009) 1-15. doi:10.1186/1471-2164-10-341. 
[30] I. Mertens, A. Vandingenen, T. Meeusen, A. De Loof, L. Schoofs, Postgenomic characterization of G-protein-coupled receptors., Pharmacogenomics. 5 (2004) 657-72. doi:10.1517/14622416.5.6.657.

[31] F. Rodet, C. Lelong, M.-P. Dubos, K. Costil, P. Favrel, Molecular cloning of a molluscan gonadotropin-releasing hormone receptor orthologue specifically expressed in the gonad, Biochim Biophys Acta. $1730 \quad$ (2005) 187-195. doi:10.1016/j.bbaexp.2005.05.012.

[32] O. Mirabeau, J. Joly, Molecular evolution of peptidergic signaling systems in bilaterians, Proc Natl Acad Sci U S A. 110 (2013) 2028-2037. doi:10.1073/pnas.1219956110//DCSupplemental.www.pnas.org/cgi/doi/10.1073/pnas.1219956110.

[33] L. Bigot, I. Beets, M.-P. Dubos, P. Boudry, L. Schoofs, P. Favrel, Functional characterization of a short neuropeptide F-related receptor in a lophotrochozoan, the mollusk Crassostrea gigas, J. Exp. Biol. 217 (2014) 2974-2982. doi:10.1242/jeb.104067.

[34] G.G. Zhang, X. Fang, X. Guo, L. Li, R. Luo, F. Xu, P. Yang, L. Zhang, X. Wang, H. Qi, Z. Xiong, H. Que, Y. Xie, P.W.H. Holland, J. Paps, Y. Zhu, F. Wu, Y. Chen, J.J.J.J.J. Wang, C. Peng, J. Meng, L. Yang, J. Liu, B. Wen, N. Zhang, Z. Huang, Q. Zhu, Y. Feng, A. Mount, D. Hedgecock, Z. Xu, Y. Liu, T. Domazet-Lošo, Y. Du, X. Sun, S.S. Zhang, B. Liu, P. Cheng, X. Jiang, J. Li, D. Fan, W. Wang, W. Fu, T. Wang, B. Wang, J. Zhang, Z. Peng, Y.Y. Li, N.N. Li, J.J.J.J.J. Wang, M. Chen, Y. He, F. Tan, X. Song, Q. Zheng, R. Huang, H.H. Yang, X. Du, L. Chen, M. Yang, P.M. Gaffney, S. Wang, L. Luo, Z. She, Y. Ming, W. Huang, S.S. Zhang, B. Huang, Y. Zhang, T. Qu, P. Ni, G. Miao, J.J.J.J.J. Wang, Q. Wang, C.E.W.C.W. Steinberg, H. Wang, N.N. Li, L. Qian, G.G. Zhang, Y.Y. Li, H.H. Yang, X. Liu, J.J.J.J.J. Wang, Y. Yin, J.J.J.J.J. Wang, The oyster genome reveals stress adaptation and complexity of shell formation., Nature. 490 (2012) 
49-54. doi:10.1038/nature11413.

524 [35] D. Monnier, J. Colas, P. Rosay, R. Hen, NKD, a developmentally regulated tachykinin receptor in Drosophila, J. Biol. Chem. 267 (1992) 1298-1302.

526

[36] R.T. Birse, E.C. Johnson, P.H. Taghert, D.R. Nässel, Widely distributed Drosophila GProtein-Coupled Receptor ( CG7887 ) is activated by endogenous tachykinin-related peptides, J. Neurobiol. 66 (2006) 33-46. doi:10.1002/neu.20189.

[37] J. Poels, H. Verlinden, J. Fichna, T. Van Loy, V. Franssens, K. Studzian, A. Janecka, R.J. Nachman, J. Vanden Broeck, Functional comparison of two evolutionary conserved insect neurokinin-like receptors, Peptides. $28 \quad$ (2007) 103-108. doi:10.1016/j.peptides.2006.06.014.

[38] J. Poels, R.T. Birse, R.J. Nachman, J. Fichna, A. Janecka, J. Vanden Broeck, D.R. Nässel, Characterization and distribution of NKD, a receptor for Drosophila tachykininrelated peptide 6, Peptides. 30 (2009) 545-556. doi:10.1016/j.peptides.2008.10.012.

[39] H. Jiang, A. Lkhagva, H. Chae, L. Simo, S. Jung, Y. Yoon, N. Lee, J.Y. Seong, Y. Park, Y. Kim, Natalisin, a tachykinin-like signaling system, regulates sexual activity and fecundity in insects, Proc Biol Sci. $10 \quad$ (2013) E3526-E3534. doi:10.1073/pnas.1310676110//DCSupplemental.www.pnas.org/cgi/doi/10.1073/pnas.1310676110.

[40] C. Zatylny-Gaudin, V. Cornet, A. Leduc, B. Zanuttini, E. Corre, G. Le Corguillé, B. Bernay, J. Garderes, A. Kraut, Y. Couté, J. Henry, Neuropeptidome of the cephalopod Sepia officinalis: identification, tissue mapping, and expression pattern of neuropeptides and neurohormones during egg laying, J. Proteome Res. 15 (2016) 48-67. doi:10.1021/acs.jproteome.5b00463.

[41] M. Conzelmann, E.A. Williams, K. Krug, M. Franz-wachtel, B. Macek, The neuropeptide complement of the marine annelid Platynereis dumerilii, BMC Genomics. 
14 (2013) 906.

549 [42] L. Liu, F. Warner, J. Conlon, E. Burcher, Pharmacological and biochemical investigation of receptors for the toad gut tachykinin peptide, bufokinin, in its species of origin., Naunyn Schmiedebergs Arch Pharmacol. 360 (1999) 187-195.

[43] J. Poels, R.J. Nachman, K.E. Åkerman, H.B. Oonk, F. Guerrero, A. De Loof, A.E. Janecka, H. Torfs, J. Vanden Broeck, Pharmacology of stomoxytachykinin receptor depends on second messenger system, Peptides. 26 (2005) 109-114. doi:10.1016/j.peptides.2004.07.015.

[44] Y. Nakajima, K. Tsuchida, M. Negishi, S. Ito, S. Nakanishi, Direct linkage of three tachykinin receptors to stimulation of both phosphatidylinositol hydrolysis and cyclic AMP cascades in transfected Chinese hamster ovary cells, J. Biol. Chem. 267 (1992) $2437-2442$.

[45] X. He, J. Zang, X. Li, J. Shao, H. Yang, J. Yang, H. Huang, L. Chen, L. Shi, C. Zhu, G. Zhang, N. Zhou, Activation of BNGR-A24 by direct interaction with tachykinin- related peptides from the silkworm Bombyx mori leads to the Gq and Gs-coupled signaling cascades, Biochemistry. 293 (2014) 6667-6678.

[46] H. Torfs, M. Detheux, H.B. Oonk, E.A. Karl, T. Van Loy, A. De Loof, G. Vassart, M. Parmentier, J. Vanden, Analysis of C-terminally substituted tachykinin-like peptide agonists by means of aequorin-based luminescent assays for human and insect neurokinin receptors, Biochem. Pharmacol. 63 (2002) 1675-1682.

[47] R. Predel, S. Neupert, S. Roth, C. Derst, D.R. Nässel, Tachykinin-related peptide precursors in two cockroach species: Molecular cloning and peptide expression in brain neurons and intestine, FEBS J. 272 (2005) 3365-3375. doi:10.1111/j.17424658.2005.04752.x.

[48] H. Torfs, H.B. Oonk, J. Vanden Broeck, J. Poels, W. Van Poyer, A. De Loof, F. Guerrero, 
R.H. Meloen, K. Åkerman, R.J. Nachman, Pharmacological characterization of STKR, an insect $\mathrm{G}$ protein-coupled receptor for tachykinin-like peptides, Arch. Insect Biochem. Physiol. 48 (2001) 39-49. doi:10.1002/arch.1056.

576

[49] J. Poels, T. Van Loy, V. Franssens, M. Detheux, R.J. Nachman, H.B. Oonk, K.E. Åkerman, G. Vassart, M. Parmentier, A. De Loof, H. Torfs, J. Vanden Broeck, Substitution of conserved glycine residue by alanine in natural and synthetic neuropeptide ligands causes partial agonism at the stomoxytachykinin receptor, J. Neurochem. 90 (2004) 472-478. doi:10.1111/j.1471-4159.2004.02506.x.

[50] T. Palanche, B. Ilien, S. Zoffmann, M.P. Reck, B. Bucher, S.J. Edelstein, J.L. Galzi, The neurokinin A receptor activates calcium and cAMP responses through dstinct conformational states, J. Biol. Chem. $276 \quad$ (2001) 34853-34861. doi:10.1074/jbc.M104363200.

[51] M. Winther, D.R. Nässel, Intestinal peptides as circulating hormones: release of tachykinin-related peptide from the locust and cockroach midgut., J. Exp. Biol. 204 (2001) 1269-1280.

[52] C. Maguire, S. León, R. Carroll, U. Kaiser, V. Navarro, Altered circadian feeding behavior and improvement of metabolic syndrome in obese Tac1-deficient mice, Int $\mathbf{J}$ Obes. 41 (2017) 1798-1804.

[53] S. Nagata, N. Morooka, S. Matsumoto, T. Kawai, H. Nagasawa, Effects of neuropeptides on feeding initiation in larvae of the silkworm, Bombyx mori, Gen. Comp. Endocrinol. 172 (2011) 90-95. doi:10.1016/j.ygcen.2011.03.004.

[54] A. Brockmann, S.P. Annangudi, T.A. Richmond, S.A. Ament, F. Xie, B.R. Southey, S.R. Rodriguez-zas, G.E. Robinson, J. V Sweedler, Quantitative peptidomics reveal brain peptide signatures of behavior., Proc. Natl. Acad. Sci. U. S. A. 106 (2009) 2383-8. doi:10.1073/pnas.0813021106. 
[55] Y. Shimizu, H. Matsuyama, T. Shiina, T. Takewaki, J.B. Furness, Tachykinins and their functions in the gastrointestinal tract, Cell. Mol. Life Sci. 65 (2008) 295-311. doi:10.1007/s00018-007-7148-1.

[56] W. Song, J.A. Veenstra, N. Perrimon, Control of lipid metabolism by tachykinin in Drosophila, Cell Rep. 9 (2014) 40-47. doi:10.1016/j.celrep.2014.08.060.

[57] M.-P. Dubos, B. Bernay, P. Favrel, Molecular characterization of an adipokinetic hormone-related neuropeptide (AKH) from a mollusk, Gen. Comp. Endocrinol. 243 (2017) 15-21. doi:10.1016/j.ygcen.2016.11.002.

[58] L. Bigot, C. Zatylny-Gaudin, F. Rodet, B. Bernay, P. Boudry, P. Favrel, Characterization of GnRH-related peptides from the Pacific oyster Crassostrea gigas., Peptides. 34 (2012) 303-10. doi:10.1016/j.peptides.2012.01.017.

[59] N.E. Rance, S.J. Krajewski, M.A. Smith, M. Cholanian, P.A. Dacks, Neurokinin B and the hypothalamic regulation of reproduction, Brain Res. 1364 (2010) 116-128. doi:10.1016/j.brainres.2010.08.059.

[60] C. Fergani, Expanding the role of tachykinins in the neuroendocrine control of reproduction, Reproduction. 153 (2017) R1-R14. doi:10.1530/REP-16-0378.

[61] J. Biran, O. Palevitch, S. Ben-dor, B. Levavi-sivan, Neurokinin Bs and neurokinin B receptors in zebrafish- potential role in controlling fish reproduction, Proc Natl Acad Sci U S A. 109 (2012) 10269-10274. doi:10.1073/pnas.1119165109.

[62] M. Aoyama, T. Kawada, M. Fujie, K. Hotta, T. Sakai, T. Sekiguchi, A novel biological role of tachykinins as an up-regulator of oocyte growth: identification of an evolutionary origin of tachykininergic functions in the ovary of the ascidian, Ciona intestinalis., Endocrinology. 149 (2008) 4346-4356. doi:10.1210/en.2008-0323. 
Cragi-TKR*

Ov-TKR*

Dm-DTKR*

Hs-NK1R*

$\mathrm{Ce}-\mathrm{TKR}$

Ci-TKR*

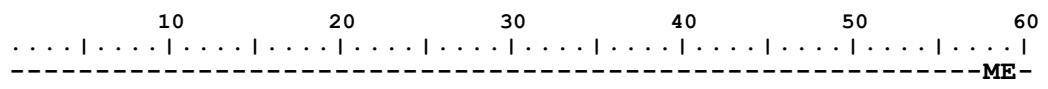

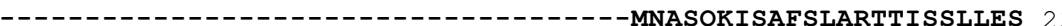
MENRSDFEADDYGDISWSNWSNWST PAGVLFSAMSSVLSASNHTPCRTLARSSPYPPVSF 60 -----------------------------------MDNVLPVDSDLSP-------- 13 -

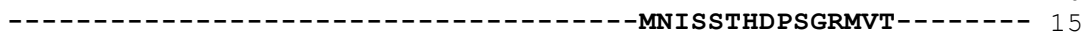

Cragi-TKR* Ov-TKR* Dm-DTKR* HS-NK1R*

$\mathrm{Ce}-\mathrm{TKR}$ Ci-TKR*

Cragi-TKR * Ov-TKR* Dm-DTKR * Hs-NK1R* $\mathrm{Ce}-\mathrm{TKR}$ Ci-TKR*

Cragi-TKR * Ov-TKR * Dm-DTKR *

Hs-NK1R* $\mathrm{Ce}-\mathrm{TKR}$ Ci-TKR*

Cragi-TKR * Ov-TKR* Dm-DTKR * HS-NK1R* Ce-TKR Ci-TKR*

Cragi-TKR * Ov-TKR* Dm-DTKR * Hs-NK1R * $\mathrm{Ce}-\mathrm{TKR}$

Ci-TKR*

Cragi-TKR* Ov-TKR* Dm-DTKR * Hs -NK1R * $\mathrm{Ce}-\mathrm{TKR}$ Ci-TKR*

Cragi-TKR * Ov-TKR* Dm-DTKR * Hs-NK1R * $\mathrm{Ce}-\mathrm{TKR}$ Ci-TKR *

Cragi-TKR * Ov-TKR* Dm-DTKR * Hs-NK1R *

$\mathrm{Ce}-\mathrm{TKR}$

Ci-TKR*

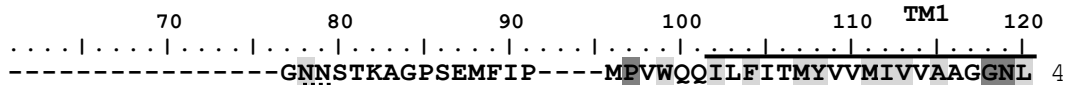
QAVQDKSSSYDVT IDWADNTTTEELSTLAPTNPFILPWWQQVFFIIIFLAMI IASIGGNL 83 NHSQTLSTDQPAVGDVEDAAEDAAASMETGSFAFVVPWWRQVLWSILFGGMVIVATGGNL 120 - - - - - - - - NISTNTS-----EPNQFVQPAWQIVLWAAAYTVIVVTSVVGNV 51 KVLNGSLINCTFOSFYDOMYQTHGVYFIFEPTPFVHPIVSQIFYGILFTLTIFLALMGNF 80 $-----------D V T A T T E D H H E D E E N P F A Q S$ PYAIFGWSVVYGLLVVVALVGNL 58

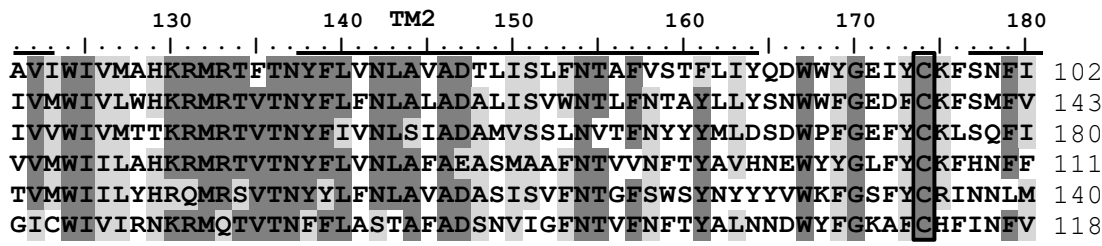
TM3
190
210
220 TM4 230
240

200

NVSTLAASVITFMSIAIDRYLAI I PLRPRLTVRVVL-AIVVIWQVSIVLAI PNLIYGKT 161 APCTTSASVFTLMAIAIDRYLAIMR--WVRMSAKVVIGLIVVIWLASCLISLPLAIYSKT 201 AMLSICASVFTLMAISIDRYVAI IRPLQPRMSKRCNLAIAAVIWLASTLISCPMMIIYRT 240 PIAAVFAS IYSMTAVAFDRYMAI I HPLOPRLSATATKVVICVIWVLALLLAFPOGYYS-- 169 GITPICASVFTMIVMS IERYYAI IHPLKKRPGRRSTVTIIIMIWFMAFLFGVPAFLASKV 200 PIGAVLASILSITVISIDREVVIMY PLRRRTSRKTAKMTIAGIWLFSLGVAFPQCFFATI 178

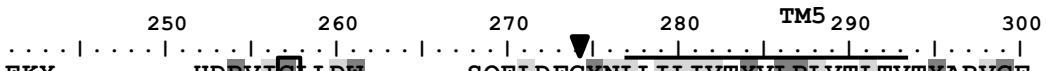
EKY------HDRVIC:LDW̄-----SQELDFGYNLLILIVTYVLPLVTLTVTYARVGF 207 ETFSYAD---GSTRTICEQEWP-GNQRSSSVELGYNI FLIIVNYFLPMFILIVTYTFLGK 257 EEVPVRG---LSNRTVCKPEWPDGPTNHSTMESLYNILIIILTYFLPIVSMTVTYSRVGI 297 TTETM------PSRVVCAIEWP--EHPNKIYEKVYHICVTVLIYFLPLLVIGYAYTVVGI 221 DVYYFYDGYTLYENPICAADNYP-GGNESLLGQVYNNGLITVQYILPLCILSAAYYRVGV 259 TTEES------GTRTTC SIQW̄P--DGVSGRMRLGYQLSFMVISYFLPLI ILAVSYVAMAL 230

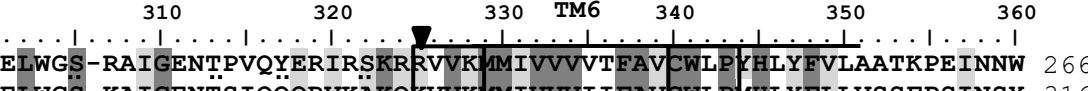
ELWGS̈-KAIGENT'S IQQ̈QRVKÄKQKVVK MMIVVVI I FAVCWLP IHLYFLLVSSFPS INSY 316 ELWGS-KTIGECT PRQVENVRSKRRVVK IMIVVVLIFAIKWLPFHSYFIITSCYPAITEA 356 TLWAS-EI PGDSSDRYHEQVSAKR KVVK MMIVVVCTFAICWLPFHIFFLLPYINPDLYLK 280 ELRKD-KTVG--DVRHAKSVAAKKKAS I ILAVVVFIFMIVWFP KNAYYLTLHLVEPIGNK 316 RLCGSNNQVGHQNETQLRRIANNK KAVR MMMLVVVVFAI CWCP KHLFFLADYIVSDSYHW 290

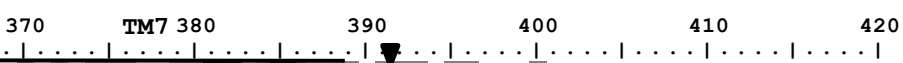

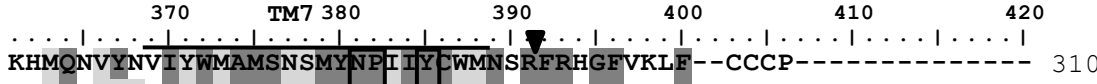
QY IQQIFLI I YWMAMSNSMYNP IIY CWMNARFRQGFKLVF--CIFP-- - - - - - - - 360 PFIQELYLAIYWLAMSNSMYNPI IY CWMNSRFRYGFKMVFRWCLFVRVGTE PFSRRENLT 416 KFIQQVYLAIMWLAMSSTMYNP I Y CCLNDRFRLGFKHAFRCCPFI--- - - - - - - - 326 MLSLYIYINIYWLGMSSTVFNPVIY IFMNKRFRVGFHHAFRWLPFVR-_- - - - - - - 363 EKIQQVYLAVFWVAMSSSMYNPFIY CWNNSRFKESFRELFHCG--------------- 333

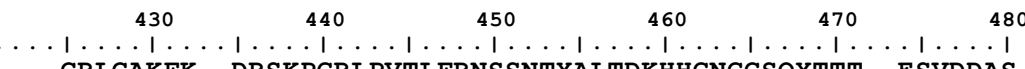

--C-CRLCAKFK- -DRSKPGRLPVTLFRNSSNTYALTDKHHGNGCSQYTTT--ESVDDAS 362 - ---CVHVQKKRR PDRN̈MTLSMSMS̈DTKGV̈̈RNG̈SLM̈HTTMENMEËSYN̈S̈̈--ET̈IOETD" 414 SRYSCSGSPDHNRIKRNDTQKSILYTCPSSPKSHRISHSGTGRSATLRNSLPAESLSSGG 476 ----SAGDYEGLEMKSTRYLQTQGSVYKVSRLETTISTVVGAHEEEPEDGPKATPSSLDL 382 - ---SDKDEYQTILSOTRPSLMP PT TMAHTDF-_-_-_-_-_-_-

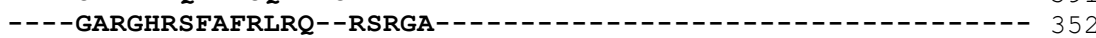

490
$\ldots 1 \ldots 1 \ldots 1 \ldots 1 \ldots 1 \ldots 1 \ldots 1 \ldots 1 \ldots 1 \ldots 1 \ldots 1 \ldots$ SGGGGHRKRLSYQQEMQQRWSGPNSATAVTNSSSTANTTQLLS 519 TSNCSSRSDSKTMTESFSFSSNVLS---- - - - - - - 407

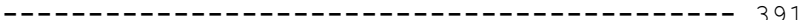

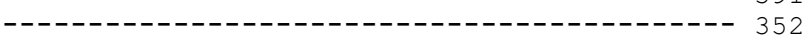

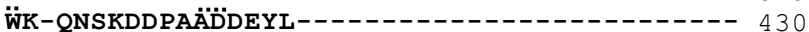

Identity Similarity

$\begin{array}{ll}41,8 \% & 59,8 \% \\ 32,3 \% & 46,4 \% \\ 32,8 \% & 52,0 \% \\ 25,5 \% & 41,7 \% \\ 27,0 \% & 43,9 \%\end{array}$

Figure 1 


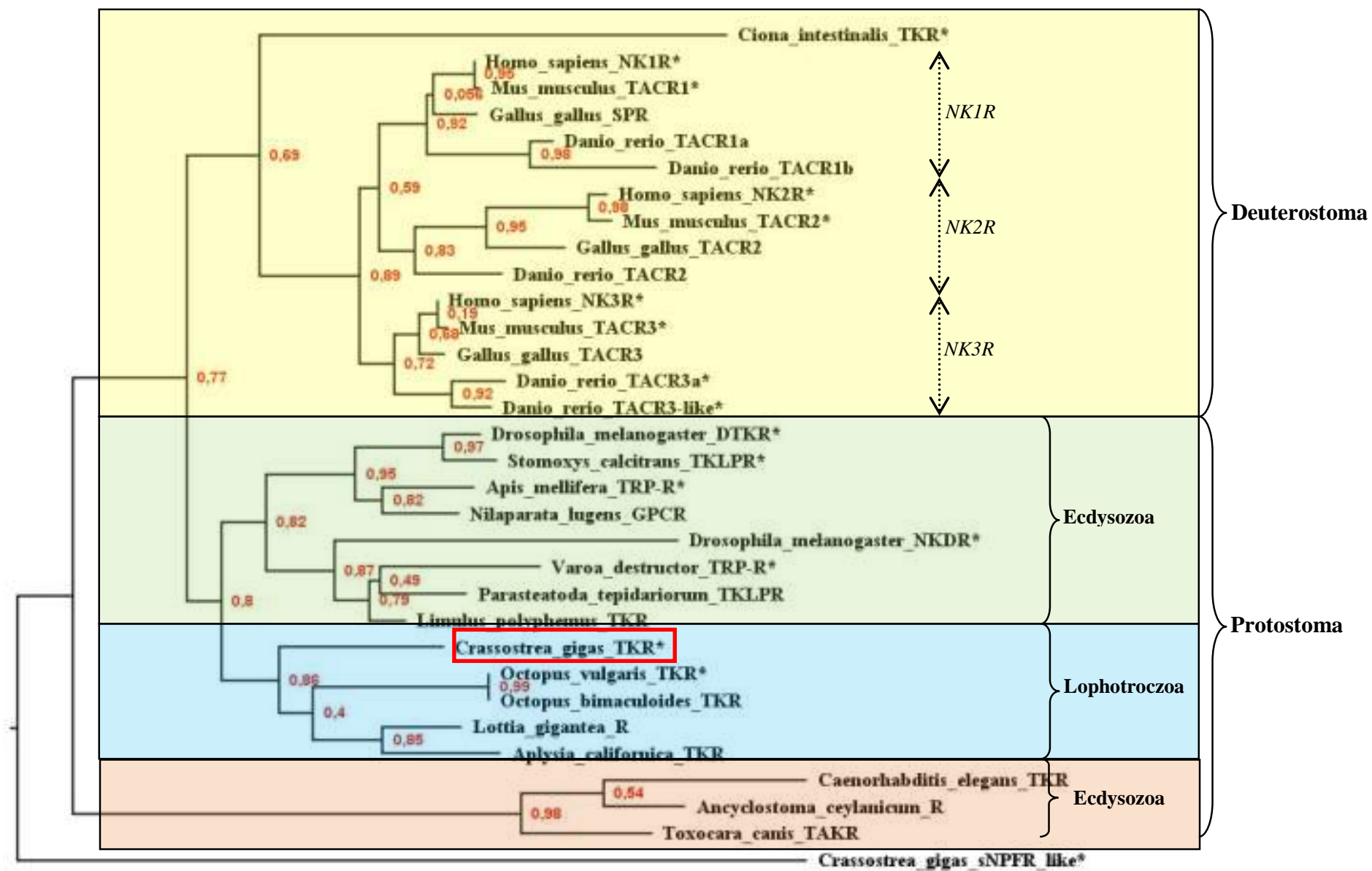

Figure. 2 
A

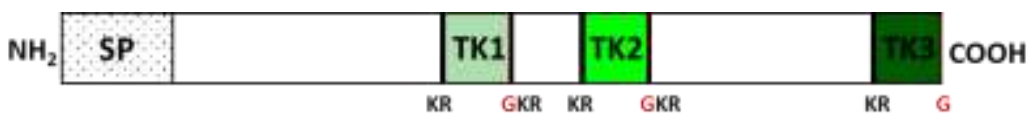

B

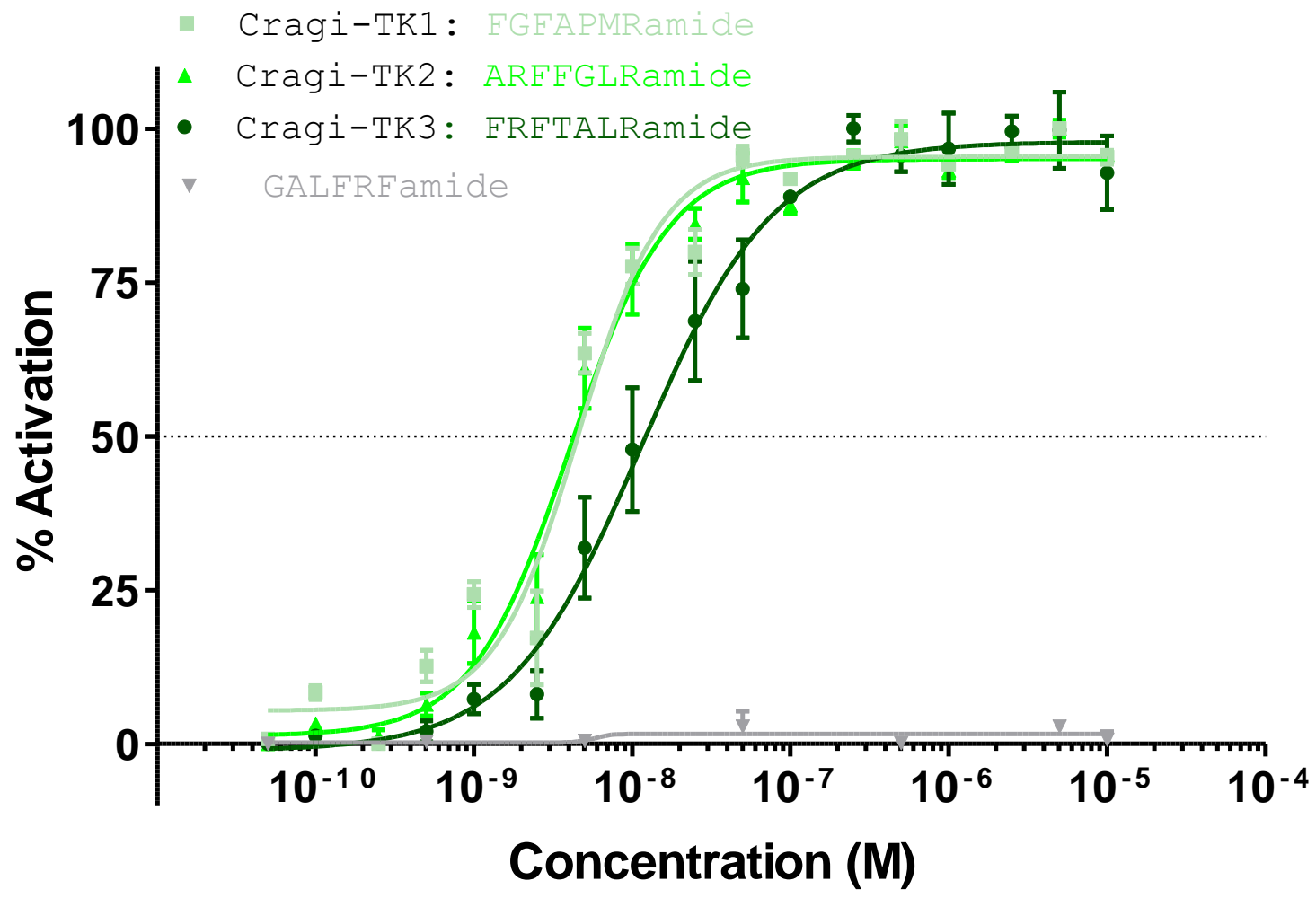

Figure 3

Table 1.

\begin{tabular}{|c|c|c|c|c|c|c|c|c|c|}
\hline \multirow{3}{*}{$\begin{array}{l}\text { Name } \\
\text { TK Vertebrate } \\
\text { consensus }\end{array}$} & & & & & & & & & $\mathrm{EC}_{50}(\mathrm{nM}$ \\
\hline & \multicolumn{8}{|c|}{ Peptide sequence } & $\mathrm{EC}_{50}(\mathrm{nM})$ \\
\hline & - & - & $\mathrm{F}$ & $X$ & G & $\mathrm{L}$ & M & amide & \\
\hline $\begin{array}{l}\text { TK Protostome } \\
\text { consensus }\end{array}$ & - & - & $\mathrm{F}$ & $\mathrm{X}$ & G & $X$ & $\mathrm{R}$ & amide & \\
\hline Cragi-TK2 & $\mathrm{A}$ & $\mathrm{R}$ & $\mathrm{F}$ & $\mathrm{F}$ & G & $\mathrm{L}$ & $\mathrm{R}$ & amide & 4.48 \\
\hline Cragi -TK2-A2 & A & A & $\mathrm{F}$ & $\mathrm{F}$ & G & $\mathrm{L}$ & $\mathrm{R}$ & amide & 7.43 \\
\hline Cragi -TK2-A3 & A & $\mathrm{R}$ & A & $\mathrm{F}$ & $\mathrm{G}$ & $\mathrm{L}$ & $\mathrm{R}$ & amide & 906.3 \\
\hline Cragi -TK2-A4 & A & $\mathrm{R}$ & $\mathrm{F}$ & A & G & $\mathrm{L}$ & $\mathrm{R}$ & amide & 14.2 \\
\hline Cragi -TK2-A5 & A & $\mathrm{R}$ & $\mathrm{F}$ & $\mathrm{F}$ & A & $\mathrm{L}$ & $\mathrm{R}$ & amide & 0.83 \\
\hline Cragi -TK2-A6 & A & $\mathrm{R}$ & $\mathrm{F}$ & $\mathrm{F}$ & G & A & $\mathrm{R}$ & amide & 0.74 \\
\hline Cragi -TK2-A7 & A & $\mathrm{R}$ & $\mathrm{F}$ & $\mathrm{F}$ & G & $\mathrm{L}$ & A & amide & 4276 \\
\hline Cragi -TK1 & $\mathrm{F}$ & G & $\mathrm{F}$ & A & $\mathrm{P}$ & M & $\mathrm{R}$ & amide & 4.6 \\
\hline Cragi -TK3 & $\mathrm{F}$ & $\mathrm{R}$ & $\mathrm{F}$ & $\mathrm{T}$ & A & $\mathrm{L}$ & $\mathrm{R}$ & amide & 11.5 \\
\hline
\end{tabular}




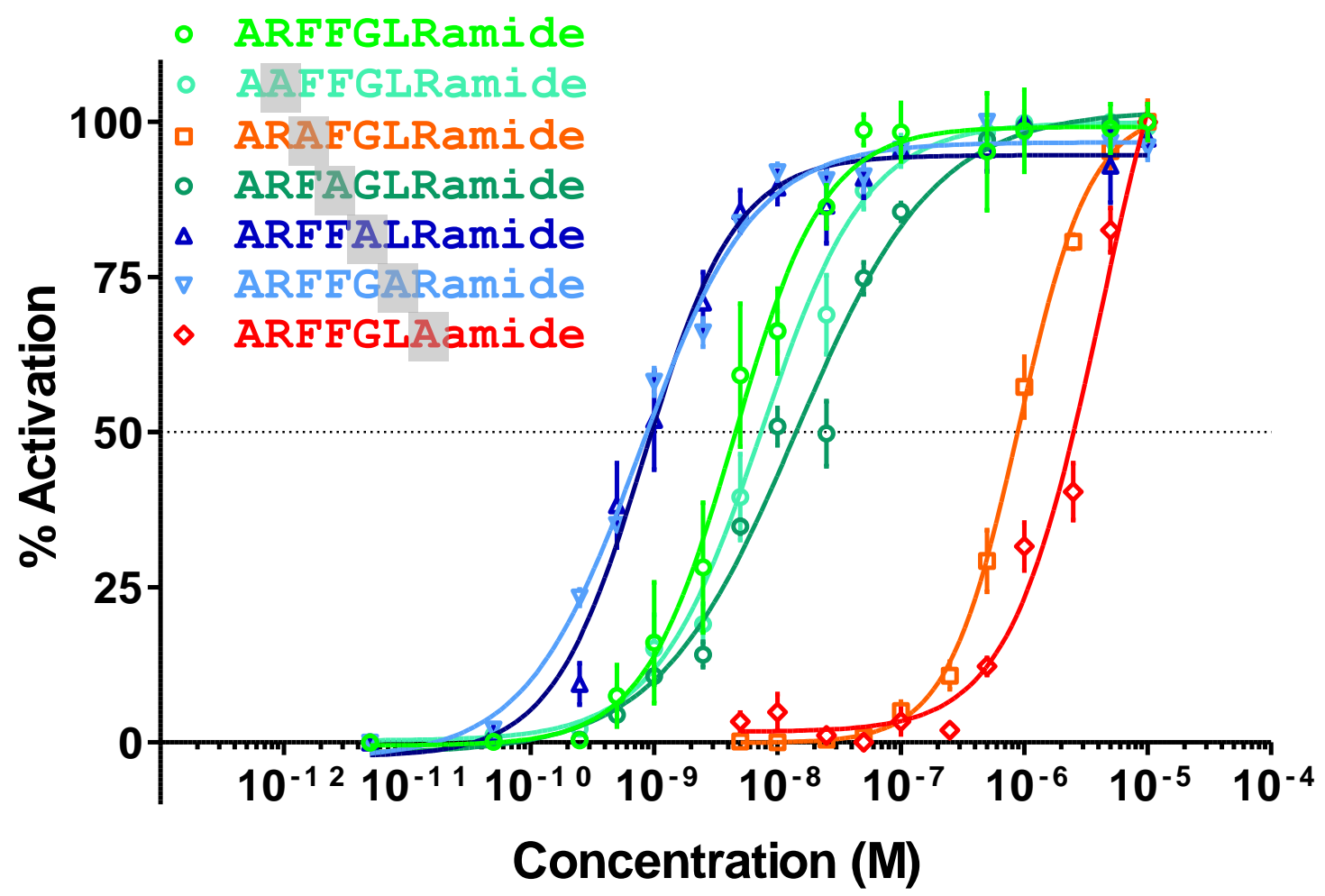

Figure 4. 

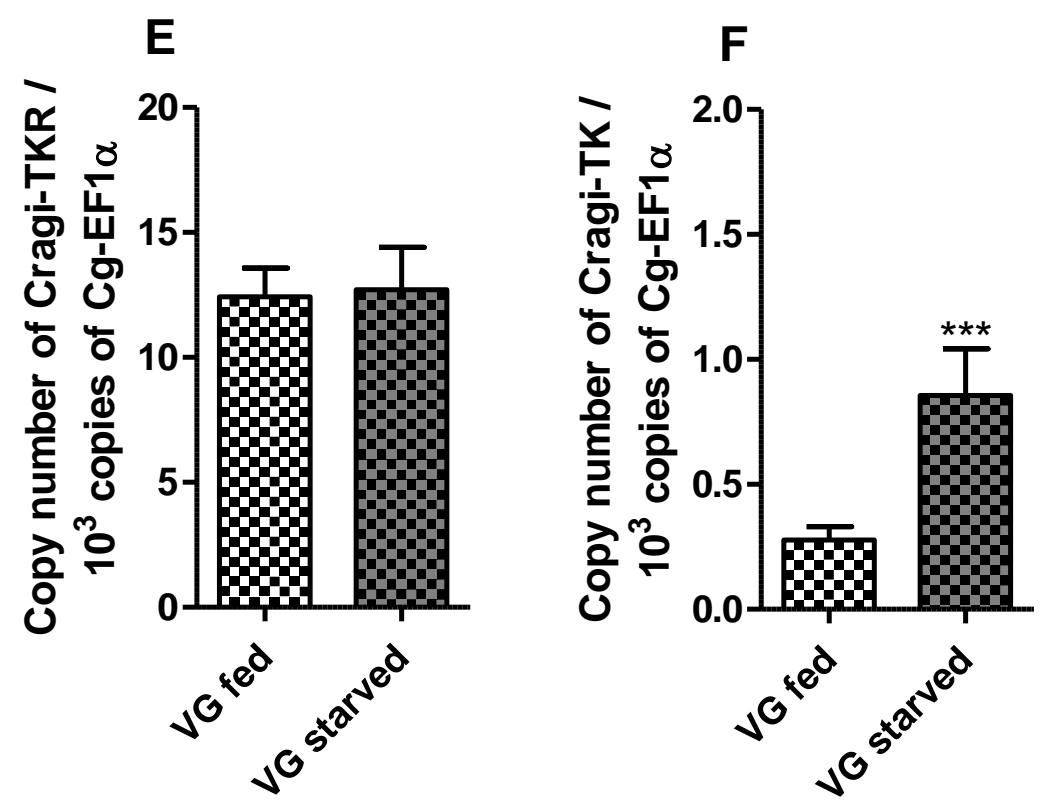

Figure 5 
Supplementary table 1: Accession numbers and references of the TKR sequences used for the alignment in Figure1

\begin{tabular}{|c|c|c|c|c|}
\hline Abbreviation & Species name & $\begin{array}{c}\text { Accession } \\
\text { number }\end{array}$ & Phylum & reference \\
\hline Cragi-TKR* & Crassostrea gigas & MF320350 & $\begin{array}{l}\text { Lophotrochozoa } \\
\text { (Mollusc) }\end{array}$ & Present paper \\
\hline Ov-TKR* & Octopus vulgaris & $\underline{Q 58 A 49}$ & $\begin{array}{l}\text { Lophotrochozoa } \\
\text { (Mollusc) }\end{array}$ & $\begin{array}{l}\text { A. Kanda, K. Takuwa-Kuroda, M. Aoyama, H. Satake, A novel tachykinin- } \\
\text { related peptide receptor of Octopus vulgaris - Evolutionary aspects of } \\
\text { invertebrate tachykinin and tachykinin-related peptide, FEBS J. } 274 \text { (2007) } \\
2229-2239 \text {. }\end{array}$ \\
\hline Dm-DTKR* & Drosophila melanogaster & $\underline{\text { P30975 }}$ & $\begin{array}{l}\text { Ecdysozoa } \\
\text { (Arthropod) }\end{array}$ & $\begin{array}{l}\text { X.J. Li, W. Wolfgang, Y.N. Wu, R.A. North, M. Forte, Cloning, } \\
\text { heterologous expression and developmental regulation of a Drosophila } \\
\text { receptor for tachykinin-like peptides., EMBO J. } 10 \text { (1991) 3221-9. }\end{array}$ \\
\hline Ci-TKR* & Ciona intestinalis & $\underline{\text { Q60GS8 }}$ & Urochordate & $\begin{array}{l}\text { H. Satake, M. Ogasawara, T. Kawada, K. Masuda, M. Aoyama, H. } \\
\text { Minakata, T. Chiba, H. Metoki, Y. Satou, N. Satoh, Tachykinin and } \\
\text { tachykinin receptor of an ascidian, Ciona intestinalis, J. Biol. Chem. } 279 \\
\text { (2004) 53798-53805. }\end{array}$ \\
\hline Hs-NK1R* & Homo sapiens & $\underline{\mathrm{P} 25103}$ & Vertebrate & $\begin{array}{l}\text { N.P. Gerard, L.A. Garraway, R.L. Eddy, T.B. Shows, H. lijima, J.L. Paquet, C. } \\
\text { Gerard, Human substance P receptor (NK-1): organization of the gene, } \\
\text { chromosome localization, and functional expression of cDNA clones., } \\
\text { Biochemistry. } 30 \text { (1991) 10640-6. }\end{array}$ \\
\hline Ce-TKRF & Caenorhabditis elegans & $\underline{044148}$ & $\begin{array}{l}\text { Ecdysozoa } \\
\text { (Nematode) }\end{array}$ & No reference \\
\hline
\end{tabular}

* functionally characterized receptors. 
Supplementary table 2: Accession numbers and references of the TKR sequences used for the phylogenetic tree in Figure2

\begin{tabular}{|c|c|c|c|c|}
\hline Abbreviation & Species name & Accession number & Phylum & reference \\
\hline Hs-NK1R* & Homo sapiens & $\underline{\mathrm{P} 25103}$ & Vertebrate & $\begin{array}{l}\text { N.P. Gerard, L.A. Garraway, R.L. Eddy, T.B. Shows, H. lijima, J.L. } \\
\text { Paquet, C. Gerard, Human substance P receptor (NK-1): } \\
\text { organization of the gene, chromosome localization, and } \\
\text { functional expression of cDNA clones., Biochemistry. } 30 \text { (1991) } \\
\text { 10640-6. }\end{array}$ \\
\hline Mm-TACR1* & Mus musculus & P30548.2 & Vertebrate & $\begin{array}{l}\text { J.B. Sundelin, D.M. Provvedini, C.R. Wahlestedt, H. Laurell, J.S. Pohl, } \\
\text { P.A. Peterson, Molecular cloning of the murine substance K and } \\
\text { substance P receptor genes., Eur. J. Biochem. } 203 \text { (1992) 625-31. }\end{array}$ \\
\hline Gg-SPR & Gallus galus & $\underline{\text { Q9W613 }}$ & Vertebrate & No reference \\
\hline Dr-TACR1a & Danio rerio & E9QCW0 & Vertebrate & $\begin{array}{l}\text { R. Lopez-Bellido, K. Barreto-Valer, R.E. Rodriguez, Expression of } \\
\text { tachykinin receptors (tacr1a and tacr1b) in zebrafish: influence of } \\
\text { cocaine and opioid receptors, J. Mol. Endocrinol. } 50 \text { (2013) 115-129. }\end{array}$ \\
\hline Dr-TACR1b & Danio rerio & $\underline{\text { I6UDB5 }}$ & Vertebrate & $\begin{array}{l}\text { R. Lopez-Bellido, K. Barreto-Valer, R.E. Rodriguez, Expression of } \\
\text { tachykinin receptors (tacr1a and tacr1b) in zebrafish: influence of } \\
\text { cocaine and opioid receptors, J. Mol. Endocrinol. } 50 \text { (2013) 115-129. }\end{array}$ \\
\hline Hs-NK2R* & Homo sapiens & P21452.3 & Vertebrate & $\begin{array}{l}\text { S. Arkinstall, I. Emergy, D. Church, A. Chollet, E. Kawashima, Calcium } \\
\text { influx and protein kinase C alpha activation mediate arachidonic acid } \\
\text { mobilization by the human NK-2 receptor expressed in Chinese } \\
\text { hamster ovary cells., FEBS Lett. } 338 \text { (1994) 75-80. }\end{array}$ \\
\hline Mm-TACR2* & Mus musculus & $\underline{\mathrm{Q} 3 K \mathrm{P} 20}$ & Vertebrate & $\begin{array}{l}\text { J.B. Sundelin, D.M. Provvedini, C.R. Wahlestedt, H. Laurell, J.S. Pohl, } \\
\text { P.A. Peterson, Molecular cloning of the murine substance K and } \\
\text { substance P receptor genes., Eur. J. Biochem. } 203 \text { (1992) 625-31. }\end{array}$ \\
\hline Gg-TACR2 & Gallus galus & E1BRR8 & Vertebrate & No reference \\
\hline Dr-TACR2 & Danio rerio & F1QPL8 & Vertebrate & No reference \\
\hline $\mathrm{Hs}-\mathrm{NK} 3 \mathrm{R}^{*}$ & Homo sapiens & $\underline{P 29371.1}$ & Vertebrate & $\begin{array}{l}\text { Y. Takeda, K.B. Chou, J. Takeda, B.S. Sachais, J.E. Krause, Molecular } \\
\text { cloning, structural characterization and functional expression of the } \\
\text { human substance P receptor., Biochem. Biophys. Res. Commun. } 179 \\
\text { (1991) } 1232-40 .\end{array}$ \\
\hline
\end{tabular}




\begin{tabular}{|c|c|c|c|c|}
\hline Mm-TACR3* & Mus musculus & EDL12172.1 & Vertebrate & $\begin{array}{l}\text { H.M. Sarau, J.A. Feild, R.S. Ames, J.J. Foley, P. Nuthulaganti, D.B. } \\
\text { Schmidt, P.T. Buckley, N.A. Elshourbagy, M.E. Brawner, M.A. Luttmann, } \\
\text { G.A. Giardina, D.W. Hay, Molecular and pharmacological } \\
\text { characterization of the murine tachykinin NK(3) receptor., Eur. J. } \\
\text { Pharmacol. } 413 \text { (2001) 143-50. }\end{array}$ \\
\hline Gg-TACR3 & Gallus galus & F1NJ82 & Vertebrate & No reference \\
\hline Dr-TACR3a & Danio rerio & H6A6A7 & Vertebrate & $\begin{array}{l}\text { J. Biran, O. Palevitch, S. Ben-dor, B. Levavi-sivan, Neurokinin Bs and } \\
\text { neurokinin B receptors in zebrafish- potential role in controlling fish } \\
\text { reproduction, Proc Natl Acad Sci U S A. } 109 \text { (2012) 10269-10274. }\end{array}$ \\
\hline $\begin{array}{l}\text { Dr-TACR3- } \\
\text { like }\end{array}$ & Danio rerio & F1R3V0 & Vertebrate & $\begin{array}{l}\text { W. Zhou, S. Li, Y. Liu, X. Qi, H. Chen, C.H.K. Cheng, X. Liu, Y. Zhang, H. } \\
\text { Lin, Molecular and Cellular Endocrinology The evolution of tachykinin } \\
\text { / tachykinin receptor ( TAC / TACR ) in vertebrates and molecular } \\
\text { identification of the TAC3 / TACR3 system in zebrafish ( Danio rerio), } \\
\text { Mol. Cell. Endocrinol. } 361 \text { (2012) 202-212. }\end{array}$ \\
\hline Dm-DTKR* & Drosophila melanogaster & P30975 & $\begin{array}{l}\text { Ecdysozoa } \\
\text { (Arthropod) }\end{array}$ & $\begin{array}{l}\text { X.J. Li, W. Wolfgang, Y.N. Wu, R.A. North, M. Forte, Cloning, } \\
\text { heterologous expression and developmental regulation of a Drosophila } \\
\text { receptor for tachykinin-like peptides., EMBO J. } 10 \text { (1991) 3221-9. }\end{array}$ \\
\hline Sc-TKLPR* & Stomoxys calcitrans & A0A1I8PID0 & $\begin{array}{l}\text { Ecdysozoa } \\
\text { (Arthropod) }\end{array}$ & $\begin{array}{l}\text { H. Torfs, R. Shariatmadari, F. Guerrero, M. Parmentier, J. Poels, W. } \\
\text { Van Poyer, E. Swinnen, A. De Loof, K. Åkerman, J. Vanden Broeck, } \\
\text { Characterization of a receptor for insect tachykinin-like peptide } \\
\text { agonists by functional expression in a stable Drosophila Schneider } 2 \\
\text { cell line, J. Neurochem. } 74 \text { (2000) 2182-2189. }\end{array}$ \\
\hline Am-TRP-R & Apis mellifera & A0A141CIU0 & $\begin{array}{l}\text { Ecdysozoa } \\
\text { (Arthropod) }\end{array}$ & $\begin{array}{l}\text { H. Jiang, D. Kim, S. Dobesh, J.D. Evans, R.J. Nachman, K. Kaczmarek, J. } \\
\text { Zabrocki, Y. Park, Ligand selectivity in tachykinin and natalisin } \\
\text { neuropeptidergic systems of the honey bee parasitic mite Varroa } \\
\text { destructor, Sci. Rep. } 6 \text { (2016) 19547. }\end{array}$ \\
\hline NI-GPCR & Nilaparvata-lugens & $\underline{\text { U3U967 }}$ & $\begin{array}{l}\text { Ecdysozoa } \\
\text { (Arthropod) }\end{array}$ & No reference \\
\hline Dm-NKDR* & Drosophila melanogaster & P30974.2 & $\begin{array}{l}\text { Ecdysozoa } \\
\text { (Arthropod) }\end{array}$ & $\begin{array}{l}\text { J. Poels, R.T. Birse, R.J. Nachman, J. Fichna, A. Janecka, J. Vanden } \\
\text { Broeck, D.R. Nässel, Characterization and distribution of NKD, a } \\
\text { receptor for Drosophila tachykinin-related peptide 6, Peptides. } 30 \\
\text { (2009) 545-556. }\end{array}$ \\
\hline
\end{tabular}




\begin{tabular}{|c|c|c|c|c|}
\hline Vd-TRP-R* & Varroa destructor & A0A141CIT9 & $\begin{array}{l}\text { Ecdysozoa } \\
\text { (Arthropod) }\end{array}$ & $\begin{array}{l}\text { H. Jiang, D. Kim, S. Dobesh, J.D. Evans, R.J. Nachman, K. Kaczmarek, J. } \\
\text { Zabrocki, Y. Park, Ligand selectivity in tachykinin and natalisin } \\
\text { neuropeptidergic systems of the honey bee parasitic mite Varroa } \\
\text { destructor, Sci. Rep. } 6 \text { (2016) } 19547 \text {. }\end{array}$ \\
\hline Pt-TKLPR & $\begin{array}{l}\text { Parasteatoda } \\
\text { tepidariorum }\end{array}$ & $\underline{X P} \quad 015910841.1$ & $\begin{array}{l}\text { Ecdysozoa } \\
\text { (Arthropod) }\end{array}$ & No reference \\
\hline Lp-TKR & Limulus polyphemus & XP 013772923.1 & $\begin{array}{l}\text { Ecdysozoa } \\
\text { (Arthropod) }\end{array}$ & No reference \\
\hline Cragi-TKR* & Crassostrea gigas & MF320350 & $\begin{array}{l}\text { Lophotrochozoa } \\
\text { (Mollusc) }\end{array}$ & Present paper \\
\hline Ov-TKR* & Octopus vulgaris & $258 A 49$ & $\begin{array}{l}\text { Lophotrochozoa } \\
\text { (Mollusc) }\end{array}$ & $\begin{array}{l}\text { A. Kanda, K. Takuwa-Kuroda, M. Aoyama, H. Satake, A novel } \\
\text { tachykinin-related peptide receptor of Octopus vulgaris - Evolutionary } \\
\text { aspects of invertebrate tachykinin and tachykinin-related peptide, } \\
\text { FEBS J. } 274 \text { (2007) 2229-2239. }\end{array}$ \\
\hline Ob-TKR & Octopus bimaculoides & XM 014930159.1 & $\begin{array}{l}\text { Lophotrochozoa } \\
\text { (Mollusc) }\end{array}$ & No reference \\
\hline Lg-R & Lottia gigantea & V4BE54 & $\begin{array}{l}\text { Lophotrochozoa } \\
\text { (Mollusc) }\end{array}$ & No reference \\
\hline Ac-TKR & Aplysia californica & XP $\quad 012936179.1$ & $\begin{array}{l}\text { Lophotrochozoa } \\
\text { (Mollusc) }\end{array}$ & No reference \\
\hline Ce-TKRF & Caenorhabditis elegans & 044148 & $\begin{array}{l}\text { Ecdysozoa } \\
\text { (Nematode) }\end{array}$ & No reference \\
\hline Ac-R & $\begin{array}{l}\text { Ancyclostoma } \\
\text { ceylanicum }\end{array}$ & A0A016WHR5 & $\begin{array}{l}\text { Ecdysozoa } \\
\text { (Nematode) }\end{array}$ & No reference \\
\hline TC-TAKR & Toxocara canis & AOA0B2V4Q7 & $\begin{array}{l}\text { Ecdysozoa } \\
\text { (Nematode) }\end{array}$ & No reference \\
\hline $\begin{array}{l}\text { Cg-sNPFR- } \\
\text { like }\end{array}$ & Crassostrea gigas & MF 320349 & $\begin{array}{l}\text { Lophotrochozoa } \\
\text { (Mollusc) }\end{array}$ & $\begin{array}{l}\text { L. Bigot, I. Beets, M.-P. Dubos, P. Boudry, L. Schoofs, P. Favrel, } \\
\text { Functional characterization of a short neuropeptide F-related } \\
\text { receptor in a lophotrochozoan, the mollusk Crassostrea gigas, J. Exp. } \\
\text { Biol. } 217 \text { (2014) 2974-2982. }\end{array}$ \\
\hline
\end{tabular}

* functionally characterized receptors. 


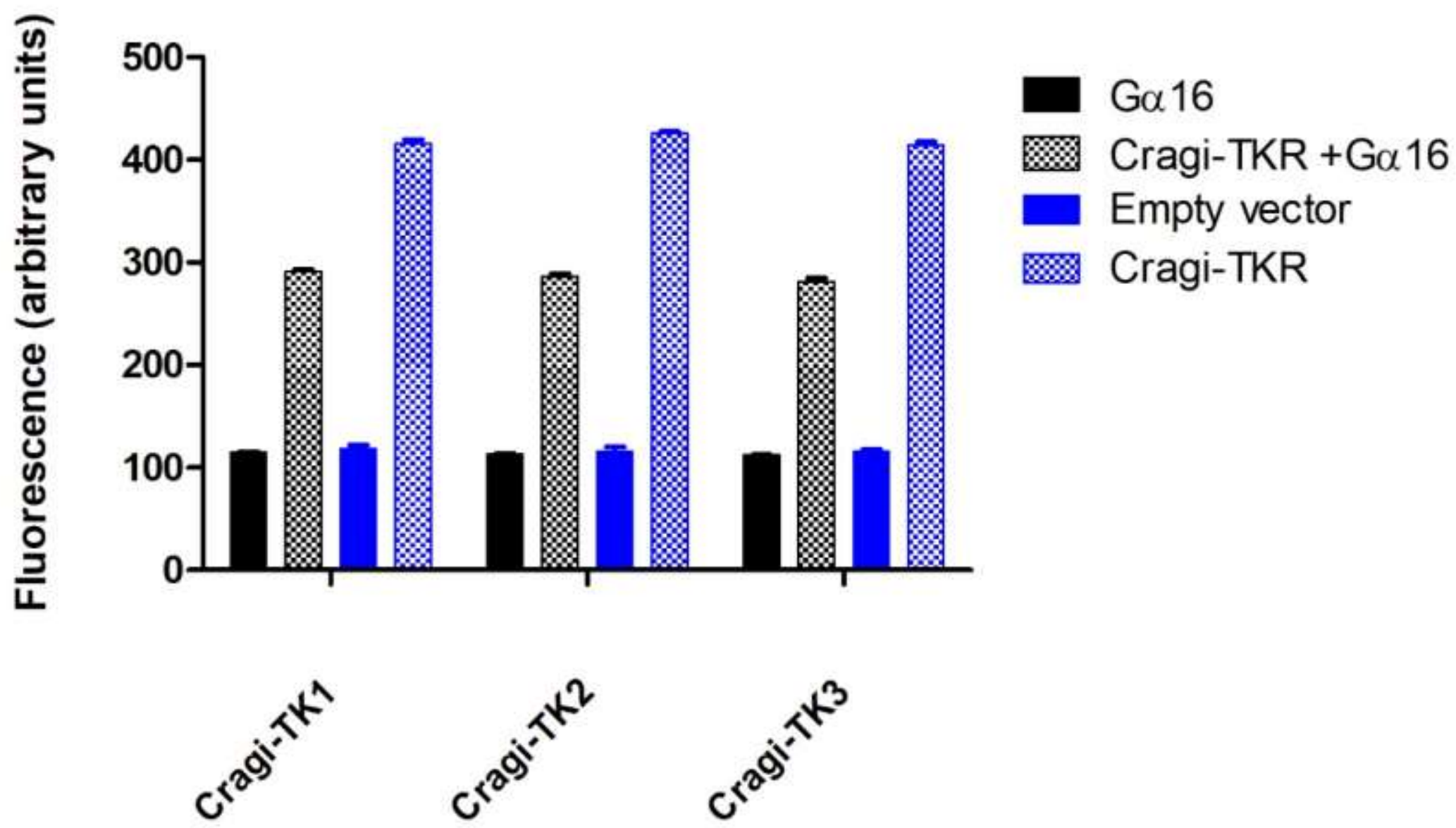

Supplementary Figure 1 : Fluorescent signal induced by Cragi-TKR expressed in HEK293T cells and challenged by Cragi-TKs at the concentration of $10^{-5} \mathrm{M}$ in absence (Cragi-TKR) or presence (Cragi-TKR $+\mathrm{G}_{\alpha 16}$ ) of the promiscuous protein $\mathrm{G}_{\alpha 16}$. $\mathrm{G}_{\alpha 16}$ expressed alone or cells transfected with an empty vector were used as negative controls. Vertical bars represent the standard error of the mean (SEM), number of replicates $n=3$. 